\title{
A Semi-Field Approach to Testing Botanical Insecticides. Effects of Natural and Analogues Annonaceous Acetogenins on Spodoptera frugiperda Smith (Lepidoptera: Noctuidae)
}

\author{
José Ruiz Hidalgo', María Gabriela Murúa ${ }^{2,3}$, Adriana Neske ${ }^{1^{*}}$ \\ ${ }^{1}$ Instituto de Química Orgánica, Facultad de Bioquímica, Química y Farmacia, UNT, Tucumán, Argentina \\ ${ }^{2}$ Instituto de Tecnologia Agroindustrial del Noroeste Argentino (ITANOA), Estación Experimental Agroindustrial Obispo \\ Colombres (EEAOC)-CONICET, Las Talitas,Tucumán, Argentina \\ ${ }^{3}$ Facultad de Ciencias Naturales e Instituto Miguel Lillo, UNT, Miguel Lillo, San Miguel de Tucumán \\ Email: ^aneske@fbqf.unt.edu.ar
}

How to cite this paper: Hidalgo, J.R., Murúa, M.G. and Neske, A. (2021) A Semi-Field Approach to Testing Botanical Insecticides. Effects of Natural and Analogues Annonaceous Acetogenins on Spodoptera frugiperda Smith (Lepidoptera: Noctuidae). Journal of Agricultural Chemistry and Environment, 10, $458-468$

https://doi.org/10.4236/jacen.2021.104031

Received: November 1, 2021

Accepted: November 26, 2021

Published: November 29, 2021

Copyright $\odot 2021$ by author(s) and Scientific Research Publishing Inc. This work is licensed under the Creative Commons Attribution-NonCommercial International License (CC BY-NC 4.0). http://creativecommons.org/licenses/by-nc/4.0/

\section{cc) (7) (2) Open Access}

\begin{abstract}
Annonaceous acetogenins enclose a large number of biological activities, among which the insecticidal stands out. Spodoptera frugiperda is a pest that affects corn crops among others and has a great capacity to develop resistance to traditional insecticides, which represents sufficient reasons for the search for new alternatives for their control. The objective of this study was to determine the appropriate concentration and screening new natural insecticides against second instar larvae of $S$. frugiperda, under glasshouse conditions on Zea mays L. Natural products such as annonaceous acetogenins and some acetylated and methoxy methylated ACG derivatives and the commercial product Lambda-cyhalotrin (LC) were evaluated. The percent mortalities of $S$. frugiperda larvae in glasshouse conditions were recorded after 24,48 and $72 \mathrm{~h}$ of treatment application. The results showed that the acetogenins tested were significantly $(\mathrm{P}<0.05)$ different in relation to pest mortality than untreated check. After $72 \mathrm{~h}$ of treatment application the highest percent mortalities were obtained with the mixture of two natural products, rolliniastatin-2 (5) $(100 \mu \mathrm{g} / \mathrm{mL})+$ squamocin $(6)(100 \mu \mathrm{g} / \mathrm{mL})+\mathrm{LC}(50 \mu \mathrm{g} / \mathrm{mL})$ that proved the most effective and gave (100\%), while rolliniastatin-2 (5) at $100 \mu \mathrm{g} / \mathrm{mL}$ alone, gave lowest percent mortality (65\%), followed by squamocin (6) at $100 \mu \mathrm{g} / \mathrm{mL}$ (55\%) and LC at $50 \mu \mathrm{g} / \mathrm{mL}(30 \%)$. The acetylated and methoxy methylated ACGs derivatives caused very low mortality (25\% - 35\%). It is recommended the mixture as a management option of $S$. frugiperda as a component of integrated pest management. The results allow us to infer that the addition of
\end{abstract}


natural ACGs synergizes the insecticidal activity of the commercial product.

Finding a new ecological alternative for insect control.

\section{Keywords}

Annonaceous Acetogenins, Biocides, Spodoptera frugiperda

\section{Introduction}

The problem that causes the use of highly toxic synthetic chemicals and pollutants from the environment makes it necessary to find new ecological alternatives for insect control. One of them would be the use of natural products that, being part of the ecosystem, would be much more compatible and less toxic to the environment. This search is supported by the fact that the plants have developed a series of defence mechanisms as a result of the millennial exposure to pathogens and predators. The selection of plants that contain natural products capable of being used as insecticides, should be easy to grow and with powerful active ingredients, with high chemical stability and optimum production [1].

Botanical insecticides have been traditionally prepared from the seeds of tropical Annona species of Annonaceae family, which has attracted a lot of attention since the 80s, due to the presence of annonaceous acetogenins (ACGs) [2] [3]. The structural characteristics of ACGs present a variety of biological activities, where insecticide activity stands out [1] [4] [5]. They are found in leaves, twigs and mostly in seeds of annonaceous plants.

Annona seed extracts may prove more useful in tropical countries where the fruits are commonly consumed or used to produce fruit juice, in which case the seeds are a waste product. For example, Leatemia and Isman [6] [7] recently demonstrated that crude ethanolic extracts or even aqueous extracts of seeds from $A$. squamosa collected at several sites in eastern Indonesia are effective against the diamondback moth, Plutella xylostella (Lep.: Plutellidae).

The insecticidal properties of ACGs isolated from the Annonaceae plants against several key crop pests in different parts of the world have repeatedly been described [8] [9] [10] [11] [12].

Our best performing natural insecticides under laboratory [13] [14] and field assays [15] were selected for subsequent greenhouse experiments.

The efficacies of spraying using mixtures of natural products and synthetic chemicals for the control of pests are crucial. Indeed, insecticides that work in synergy when mixed together are an avenue to explore in Spodoptera frugiperda (J.E. Smith) (Lep. Noctuidae) control. We think that the work with pesticides mixtures with different modes of action may delay the onset of resistance developing in pest populations. However, some problems need to be considered when two or more insecticides are mixed together especially phytotoxicity.

In this work, it is proposed to carry out semi-field assays with the generalist $S$. 
frugiperda [16], considered a key pest of maize in north-eastern Argentina, and "maíz Leales 25 " was chosen for its adaptability to subtropical climates, prevailing in the north and center of the country. The aim was to evaluate the dose-mortality values, produced by three chloroform seed extracts from Annona squamosa, $A$. muricata and $A$. montana, four pure ACGs and two semisynthetic analogues obtained by chemical and enzymatic methods on $S$. frugiperda.

\section{Materials and Methods}

\subsection{Extracts and Equipment}

Extraction and purification of natural ACGs. Chloroform seed extracts were partitioned between chloroform and water. Then, chloroform was evaporated, extracts cromatographed on a silica gel column (chloroform-ethyl acetate-methanol gradient) and column fractions processed on a Phenomenex C18 HPLC column $(25 \mathrm{~cm} \times 1 \mathrm{~cm}$ i.d., $5 \mu \mathrm{m}$ particle size $)$ to yield pure ACGs. All reagents and solvents used in study are of analytical grade and procured locally. Structural characterization was achieved by Infrared spectroscopy (IR), Nuclear Magnetic Resonance ${ }^{1} \mathrm{H}$ and ${ }^{13} \mathrm{C}\left({ }^{1} \mathrm{H}-\mathrm{NMR},{ }^{13} \mathrm{C}-\mathrm{NMR}\right)$, and Electron Impact Mass Spectrometry (EI-MS). IR spectra were obtained by a Shimadzu IR-408 spectrometer, with $\mathrm{KBr}$ pellets. Spectrometer $1 \mathrm{D}\left({ }^{1} \mathrm{H},{ }^{13} \mathrm{C}\right.$, and DEPT $)$ and $2 \mathrm{D}\left({ }^{1} \mathrm{H}-{ }^{1} \mathrm{H} \mathrm{COSY}\right.$, HSQC, HMBC, and NOESY) spectra were recorded on an Bruker $400 \mathrm{MHz}$ spectrometer, using the solvent signal as reference $\left(\mathrm{CDCl}_{3}\right.$ at $\delta 7.26$ and 77.0 ppm).

EIMS and HRQ-TOFMS 5600 LC/MS/MS were performed on a Thermo Polaris $\mathrm{Q}$ and Sciex spectrometer, respectively.

\subsection{ACGs Derivatives}

\subsubsection{Enzimatic Method}

Acetylated analogs (enzymatic acetylation) were obtained by dissolving the ACG in mixture of dichloro-methane $(5 \mathrm{ml})$ and vinyl acetate $(1.2 \mathrm{~mol}$ per $\mathrm{OH}$ group to be acetylated) in a screw cap vial. Then lipase (Candida antarctica B) was added (10\% - 30\% of ACG weight) and vial placed on an orbital shaker $\left(37^{\circ} \mathrm{C}\right.$, 150 - $200 \mathrm{rpm}$ ) until completion of reaction as shown by TLC. Finally, lipase was filtered and washed with dichloro-methane. Solvent was removed from the liquid fraction in a rotary vacuum evaporator $\left(30^{\circ} \mathrm{C}\right)$ and aceylated compounds purified by flash column chromatography [17].

\subsubsection{Chemical Method}

Methoxy methylated ACG derivatives were obtained by reaction with $N, N$-diisopropylethylamine and methoxymethyl chloride in dichloromethane under a nitrogen atmosphere. At completion of the reaction (shown by TLC) solvent was removed, residue chromatographed on flash column and chemical structure of products assessed by ${ }^{1} \mathrm{H}-\mathrm{NMR}$ and ${ }^{13} \mathrm{C}-\mathrm{NMR}$ by comparison with ACGs precursors [17]. 


\subsection{A Semi-Field Approach to Testing Botanical Insecticides}

\subsubsection{Test Insects: Diet and Formulations}

Spodoptera frugiperda larvae were obtained from our laboratory population, were kept in a chamber with a temperature of $25^{\circ} \mathrm{C} \pm 1^{\circ} \mathrm{C}$, a relative humidity of $50 \% \pm 10 \%$, and a photoperiod of 10:10 (light:dark). The larval diet was prepared as follows: yeast, $3 \mathrm{~g}$; milled and boiled bean, $250 \mathrm{~g}$; wheat germ, $12.5 \mathrm{~g}$; agaragar, $12.5 \mathrm{~g}$; ascorbic acid, $1.5 \mathrm{~g}$; methyl p-hydroxybenzoate, $1.5 \mathrm{~g}$; formaldehyde $38 \%$ water solution, $4 \mathrm{ml}$; water, $500 \mathrm{ml}$. Acetone solutions of natural ACG and derivatives were prepared $\left(100 \mu \mathrm{g} \cdot \mathrm{ml}^{-1}\right)$ in which second.

\subsubsection{Treatment Formulations}

Test solution. The subextracts at 250,500 and $750 \mu \mathrm{g} / \mathrm{mL}$, and the pure natural and derivative ACGs at $100 \mu \mathrm{g} / \mathrm{mL}$, were prepared with destilled water and polysorbate 20 (Tween $20^{\circledR}$ ) as nonionic surfactant.

Test commercial product. Lambda-cyhalothrin was applied in this study as positive control. The test solution contained 250,125 and $50 \mu \mathrm{g} / \mathrm{mL}$ of destilled water. These solutions served as toxic reference treatments and destilled water served as benign control treatment.

\subsubsection{Semi-Field Assay Design}

The test is carried out with seeds of Zea mays L. variety "Leales 25". They are planted individually between 100 and 150 on a surface of $0.125 \mathrm{~m}^{2}$ in an artificial habitat. During their development, the seedlings were not treated with protection products. The growth stage of plants used was V3 [18] [19]. Then the leaves were cut and sprayed with the products to be tested ( 20 repetitions for each control and treated compound) to the point of dripping using manual sprayers under a hood. Once dry, approximately after 3 to $4 \mathrm{~h}$, the petiole of a leaf of 4 to 6 $\mathrm{cm}$ long is introduced in a $1.5 \mathrm{ml}$ eppendorf containing $1.5 \%$ agar to avoid foliar dehydration. Each eppendorf is placed in a test tube of $1.2 \mathrm{~cm}$ internal diameter and $15 \mathrm{~cm}$ high and were completely isolated from any other insects. A third instar larva of $S$. frugiperda is introduced into each tube. The assays were performed in triplicate for each dose of all products tested as well as with the commercial insecticide, Lambda-cyhalothrin, and is carried out in a chamber with a temperature of $25^{\circ} \mathrm{C} \pm 2{ }^{\circ} \mathrm{C}$, a relative humidity of $75 \% \pm 5 \%$, and a photoperiod of 16:8 (light:dark).

\subsubsection{Toxicity Test}

After 24, 48 and $72 \mathrm{~h}$ of the treatment application, the toxic effect of the different compounds was evaluated through the mortality of the larvae. Dead larvae were counted and removed.

\section{Results}

\section{Toxicity Test}

Subextracts of Annona species, natural and derivatives ACGs. 
We carried out evaluations of insecticidal action at medium-scale, which simulated field conditions, in order to verify the real effectiveness of the compounds tested. We selected for these assays, three chloroform sub-extracts of Annona species: A. squamosa (SE1), A. montana (SE2) and A. muricata (SE3), eleven natural ACGs: annonacin (1), cis-annonacin (2), annoreticuin (3), montanacin-L (4), rolliniastatin-2 (5), squamocin (6), asiminecin (7), asiminacin (8), montanacin-D (9), montanacin-E (10) and montanacin-K (11), and two structurally modified ACGs: tri-acetylated squamocin (12) and tri-methoxymethylated squamocin (13) (Figure 1), which showed significant toxicity on larvae of Spodoptera frugiperda in laboratory tests.

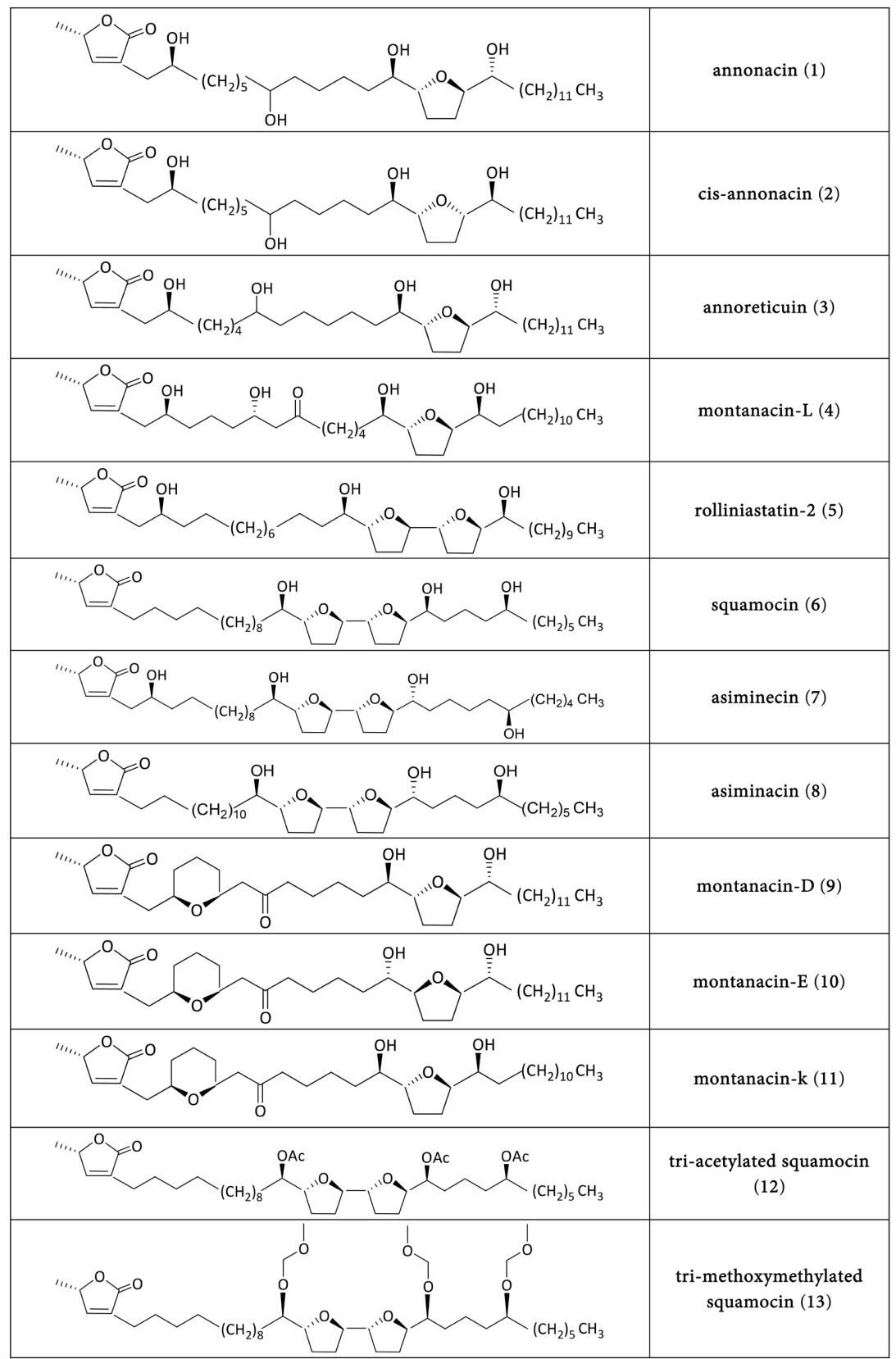

Figure 1. Natural ACGs evaluated for their toxicity against Spodoptera frugiperda. 
Table 1 shows that of the three subextracts tested, SE1 at 250 and $500 \mu \mathrm{g} / \mathrm{mL}$, produced the highest toxicity on larvae of $S$. frugiperda in early stages, causing mortality of $45 \%$ and $60 \%$, respectively at $72 \mathrm{~h}$ after application. Among eleven natural ACGs tested, rolliniastatin-2 (5) and squamocin (6) at $100 \mu \mathrm{g} / \mathrm{mL}$, were found to be the most toxic against $S$. frugiperda, causing larval mortality of $65 \%$ and 55\%, respectively. Both structurally modified ACGs 12 and 13, showed caused very low mortality ( $35 \%$ and $25 \%$, respectively) in the same experimental conditions.

Table 1. Toxic effects of botanical insectides on $S$. frugiperda.

\begin{tabular}{|c|c|c|c|c|}
\hline Compounds & $\begin{array}{c}\text { Concentration } \\
{[\mu \mathrm{g} / \mathrm{mL}]}\end{array}$ & $\begin{array}{c}\text { Dead larvae } \\
24 \mathrm{~h}(\%)\end{array}$ & $\begin{array}{c}\text { Dead larvae } \\
48 \text { h (\%) }\end{array}$ & $\begin{array}{c}\text { Dead larvae } \\
72 \mathrm{~h}(\%)\end{array}$ \\
\hline \multirow[t]{2}{*}{ LC } & 250 & 20 & 80 & 100 \\
\hline & 250 & 0 & 5 & 45 \\
\hline \multirow[t]{3}{*}{ SE1 } & 500 & 0 & 15 & 60 \\
\hline & 750 & 0 & 10 & 65 \\
\hline & 250 & 0 & 5 & 25 \\
\hline \multirow[t]{3}{*}{ SE2 } & 500 & 0 & 5 & 35 \\
\hline & 750 & 0 & 10 & 40 \\
\hline & 250 & 0 & 0 & 25 \\
\hline \multirow[t]{2}{*}{ SE3 } & 500 & 0 & 5 & 40 \\
\hline & 750 & 0 & 15 & 50 \\
\hline 1 & 100 & 0 & 0 & 60 \\
\hline 2 & 100 & 0 & 0 & 55 \\
\hline 3 & 100 & 0 & 0 & 5 \\
\hline 4 & 100 & 0 & 0 & 0 \\
\hline 5 & 100 & 0 & 0 & 65 \\
\hline 6 & 100 & 0 & 0 & 55 \\
\hline 7 & 100 & 0 & 0 & 0 \\
\hline 8 & 100 & 0 & 0 & 30 \\
\hline 9 & 100 & 0 & 0 & 20 \\
\hline 10 & 100 & 0 & 0 & 5 \\
\hline 11 & 100 & 0 & 0 & 20 \\
\hline 12 & 100 & 0 & 0 & 35 \\
\hline 13 & 100 & 0 & 0 & 25 \\
\hline
\end{tabular}

Commercial product: (LC) lambda-cyhalotrin. Subextracts: (SE1) A. squamosa, (SE2) A. montana, (SE3) A. muricata. Natural ACGs: (1) annonacin, (2) cis-annonacin, (3) annoreticuin, (4) montanacin-L, (5) rolliniastatin-2, (6) squamocin, (7) asiminecin, (8) asiminacin, (9) montanacin-D, (10) montanacin-E, (11) montanacin-K. Structurally modified ACGs: (12) tri-acetylated squamocin, (13) tri-methoxymethylated squamocin. 
It could be inferred that the hydroxyl groups flanking THF are of great influence on biological activity. This becomes clear when we observe how the toxicity of these compounds decreases when these groups are blocked by acetylation or methoxy-methylation reactions. The natural ACGs were the most promising compounds for $S$. frugiperda larvae control.

Figure 2 shows the leaf damage caused by the larvae during the test with SE1 $(250 \mu \mathrm{g} / \mathrm{mL})$. The results of leaf damage caused by $S$. frugiperda larvae are consistent with the toxicity observed under the same experimental conditions (Figure 3). SE1 causes a marked decrease in larval growth with respect to control larvae as well as inefficiency in the conversion of absorbed larval nutrients into biomass. These results would be consistent with a chronic poisoning that leads the larvae to death.

Given that isolated natural products have less toxic phytosanitary properties than commercial ones and in the search to optimize the concentration and propose the formulation of a selective insecticide for $S$. frugiperda, we evaluate the control capacity of the insect with mixtures of subextracts, natural products and the commercial product as shown in Table 2.

Table 2. Toxic effects of the different formulations on $S$. frugiperda.

\begin{tabular}{|c|c|c|c|}
\hline Concentration & $\begin{array}{l}\text { Dead larvae } \\
24 \mathrm{~h}(\%)\end{array}$ & $\begin{array}{l}\text { Dead larvae } \\
48 \mathrm{~h}(\%)\end{array}$ & $\begin{array}{l}\text { Dead larvae } \\
72 \mathrm{~h}(\%)\end{array}$ \\
\hline $\mathrm{LC} 250 \mu \mathrm{g} / \mathrm{mL}$ & 20 & 80 & 100 \\
\hline $\mathrm{LC} 125 \mu \mathrm{g} / \mathrm{mL}$ & 15 & 40 & 60 \\
\hline $\mathrm{LC} 50 \mu \mathrm{g} / \mathrm{mL}$ & 0 & 5 & 30 \\
\hline SE1 $250 \mu \mathrm{g} / \mathrm{mL}$ & 0 & 5 & 45 \\
\hline SE1 $125 \mu \mathrm{g} / \mathrm{mL}+\mathrm{LC} 125 \mu \mathrm{g} / \mathrm{mL}$ & 5 & 35 & 80 \\
\hline $\mathrm{SE} 1125 \mu \mathrm{g} / \mathrm{mL}+\mathrm{LC} 50 \mu \mathrm{g} / \mathrm{mL}$ & 0 & 25 & 65 \\
\hline rolliniastatin-2 (5) $100 \mu \mathrm{g} / \mathrm{mL}$ & 0 & 0 & 65 \\
\hline $\begin{array}{l}\text { rolliniastatin-2 (5) } 100 \mu \mathrm{g} / \mathrm{mL}+\mathrm{LC} 125 \\
\mu \mathrm{g} / \mathrm{mL}\end{array}$ & 15 & 60 & 90 \\
\hline rolliniastatin-2 (5) $50 \mu \mathrm{g} / \mathrm{mL}+\mathrm{LC} 125 \mu \mathrm{g} / \mathrm{mL}$ & & 40 & 75 \\
\hline rolliniastatin-2 (5) $50 \mu \mathrm{g} / \mathrm{mL}+\mathrm{LC} 50 \mu \mathrm{g} / \mathrm{mL}$ & 0 & 10 & 65 \\
\hline squamocin (6) $100 \mu \mathrm{g} / \mathrm{mL}$ & 0 & 0 & 55 \\
\hline squamocin (6) $100 \mu \mathrm{g} / \mathrm{mL}+\mathrm{LC} 125 \mu \mathrm{g} / \mathrm{mL}$ & 10 & 55 & 85 \\
\hline squamocin (6) $50 \mu \mathrm{g} / \mathrm{mL}+\mathrm{LC} 125 \mu \mathrm{g} / \mathrm{mL}$ & 5 & 35 & 80 \\
\hline squamocin (6) $50 \mu \mathrm{g} / \mathrm{mL}+\mathrm{LC} 50 \mu \mathrm{g} / \mathrm{mL}$ & 0 & 5 & 45 \\
\hline $\begin{array}{l}\text { squamocin (6) } 100 \mu \mathrm{g} / \mathrm{mL}+\text { rolliniastatin-2 } \\
\text { (5) } 100 \mu \mathrm{g} / \mathrm{mL}+\mathrm{LC} 50 \mu \mathrm{g} / \mathrm{mL}\end{array}$ & 15 & 80 & 100 \\
\hline $\begin{array}{l}\text { squamocin (6) } 50 \mu \mathrm{g} / \mathrm{mL}+\text { rolliniastatin-2 (5) } \\
50 \mu \mathrm{g} / \mathrm{mL}+\mathrm{LC} 50 \mu \mathrm{g} / \mathrm{mL}\end{array}$ & 0 & 35 & 75 \\
\hline
\end{tabular}



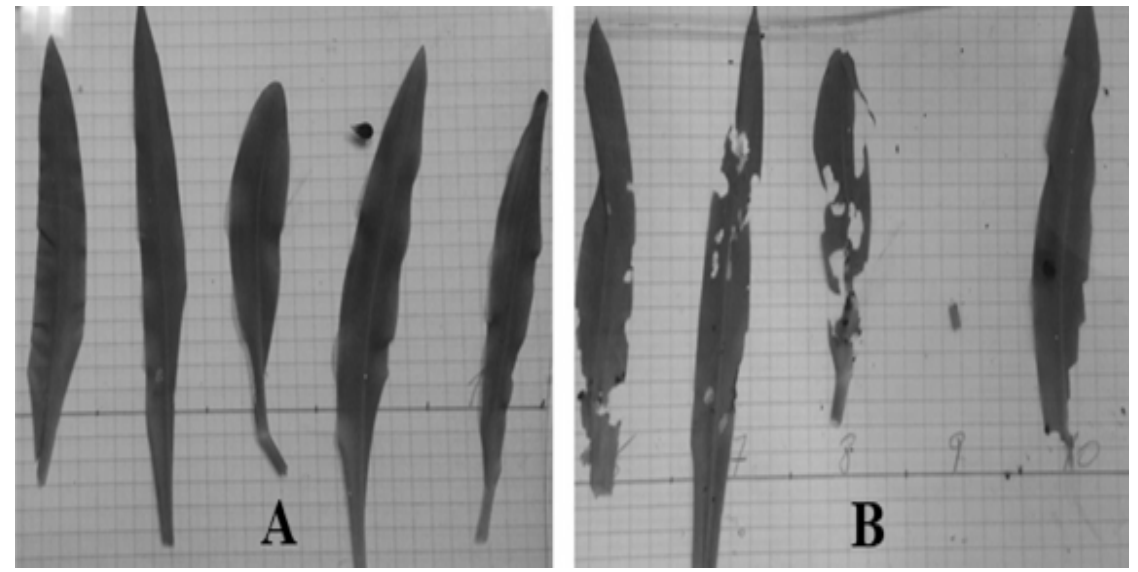

Figure 2. A: start of the assay; B: end of the assay, foliar damage with SE1 at $250 \mu \mathrm{g} / \mathrm{mL}$.

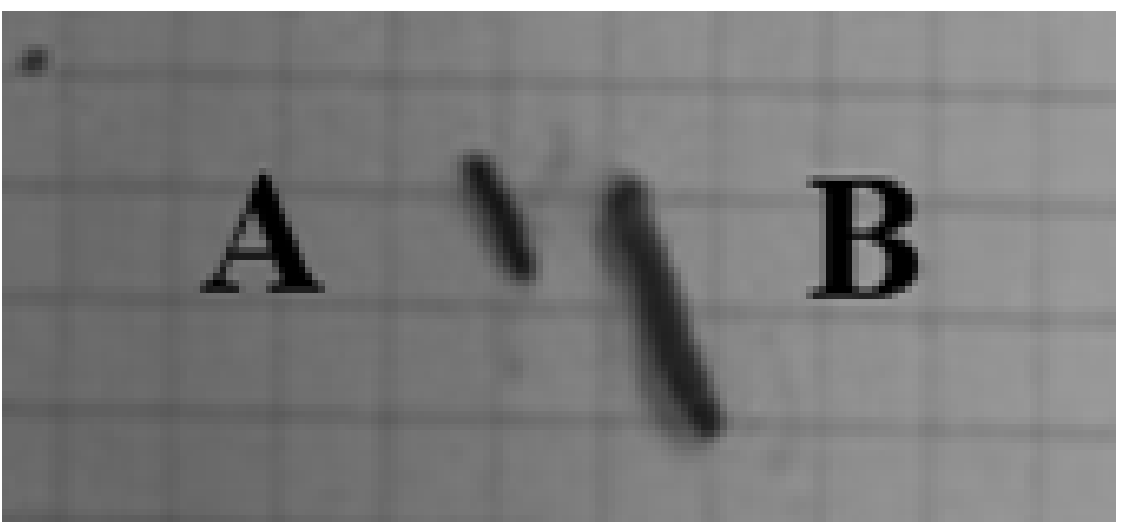

Figure 3. A: larvae treated with A. squamosa extract $(250 \mu \mathrm{g} / \mathrm{mL})$; B: control larvae.

The optimal binary and ternary formulations for the control of larvae resulted from the combination of: 1) rolliniastatin-2 (5) $(100 \mu \mathrm{g} / \mathrm{mL})+\mathrm{LC}(125 \mu \mathrm{g} / \mathrm{mL})$ which caused $90 \%$ of larval mortality at $72 \mathrm{~h}$ after application and 2) rolliniastatin-2 (5) $(100 \mu \mathrm{g} / \mathrm{mL})+$ squamocin $(6)(100 \mu \mathrm{g} / \mathrm{mL})+\mathrm{LC}(50 \mu \mathrm{g} / \mathrm{mL})$ that caused $100 \%$ of larval mortality at $72 \mathrm{~h}$ after application (Table 2 ).

The results indicate that control of the larvae of $S$. frugiperda can be achieved, significantly reducing the dose of the commercial insecticide (LC $50 \mu \mathrm{g} / \mathrm{mL}$ ), to a fifth of the effective concentration recommended by the manufacturer. The mixture with natural ACGs (rolliniastatin-2 and squamocin) at very low concentration $(100 \mu \mathrm{g} / \mathrm{mL})$ triplicate the toxic effect, causing $100 \%$ lethality in $S$. frugiperda larvae. These results allow us to infer that the addition of natural ACGs synergizes the insecticidal activity of the commercial product.

\section{Discussion}

Spodoptera frugiperda is a polyphagous lepidopteran, a major pest in corn fields where it feeds on leaves, tassels and ears of corn. Severe damages are particularly caused during its early larval stages [16]. For this reason, a candidate compound for the control of this pest should preferably produce larval mortality. In agreement with previous work [8] [13] [14], this report highlights rolliniastatin-2 and 
squamocin as the most promising compounds for $S$. frugiperda larvae control. Treatment with rolliniastatin-2 and squamocin are environmentally selective and shows an excellent degree of selectivity towards beneficial insects minimizing the detrimental effects of pesticides on natural enemies, allowing their survival and sustainable control of pests [15]. Biological activity of ACGs has been little studied in vivo, therefore more tests are required to verify the potential of these compounds in real scenarios.

\section{Conclusions and Recommendations}

These studies clearly indicated the efficacious of natural ACGs such as squamocin, rolliniastatin-2 and a mixture of both with LC showed good efficacy in controlling $S$. frugiperda larvae, they can be used in conjunction for integrated pest management. Therefore, it is recommended that mixture of rolliniastatin-2 (5) $(100 \mu \mathrm{g} / \mathrm{mL})+$ squamocin $(6)(100 \mu \mathrm{g} / \mathrm{mL})+\mathrm{LC}(50 \mu \mathrm{g} / \mathrm{mL})$ are used as a management option of $S$. frugiperda as components of integrated pest management.

The efficacies of spraying using mixtures of natural products and synthetic chemicals for the control of pests are crucial. Indeed, insecticides that work in synergy when mixed together are an avenue to explore in Spodoptera frugiperda.

\section{Acknowledgements}

This work was funded by the Research Council of the National University of Tucuman (CIUNT) and The National Council of Scientific and Technical Research (CONICET).

\section{Conflicts of Interest}

The authors declare no conflicts of interest regarding the publication of this paper.

\section{References}

[1] Castillo, L., Castillo, L.E., Jimenez, J.J. and Delgado, M.A. (2010) Secondary Metabolites of the Annonaceae, Solanaceae and Meliaceae Families Used as Biological Control of Insects. Tropical and Subtropical Agroecosystems, 12, 445-462.

[2] Neske, A., Hidalgo, J.R., Cabedo, N. and Cortes, D. (2020) Acetogenins from Annonaceae Family. Their Potential Biological Applications. Phytochemistry, 174, Article ID: 112332. https://doi.org/10.1016/j.phytochem.2020.112332

[3] Liaw, C.C., Liou, J.R., Wu, T.Y., Chang, F.R. and Wu, Y.C. (2016) Acetogenins from Annonaceae. In: Kinghorn, A., Falk, H., Gibbons, S. and Kobayashi, J., Eds., Progress in the Chemistry of Organic Natural Products 101. Progress in the Chemistry of Organic Natural Products, vol 101. Springer, Cham. https://doi.org/10.1007/978-3-319-22692-7_2

[4] Isman, M.B. (2006) Botanical Insecticides, Deterrents, and Repellents in Modern Agriculture and an Increasingly Regulated World. Annual Review of Entomology, 51, 45-66. https://doi.org/10.1146/annurev.ento.51.110104.151146

[5] Ocampo, D.M. and Ocampo, R. (2006) Bioactividad de la familia annonaceae. Revista Universidad de Caldas, 26, 135-155. 
[6] Leatemia, J.A. and Isman, M.B. (2004) Insecticidal Activity of Crude Seed Extracts of Annona spp., Lansium Domesticum and Sandoricum koetjape against Lepidopteran Larvae. Phytoparasitica, 32, 30-37. https://doi.org/10.1007/BF02980856

[7] Leatemia, J.A. and Isman, M.B. (2004) Efficacy of Crude Seed Extracts of Annona squamosa against Diamondback Moth, Plutella xylostella L. in the Greenhouse. International Journal of Pest Management, 50, 129-133. https://doi.org/10.1080/096708704100001691821

[8] Tolosa, D., Alvarez, C.O., Bardón, A. and Neske, A. (2012) Insecticidal Effects of Acetogenins from Rollinia Occidentalis Seed Extract. Natural Product Communications, 7, 1645-1646. https://doi.org/10.1177/1934578X1200701226

[9] do Prado Ribeiro, L., Gonçalves, G.L.P., Bicalho, K.U., Fernandes, J.B. and Vendramim, J.D. (2020) Rolliniastatin-1, a Bis-Tetrahydrofuran Acetogenin: The Major Compound of Annona mucosa Jacq. (Annonaceae) Has Potent Grain-Protective Properties. Journal of Stored Products Research, 89, Article ID: 101686.

https://doi.org/10.1016/j.jspr.2020.101686

[10] Wan, J., Huang, C., Li, C.y., Zhou, H.x., Ren, Y.l., Li, Z.y., Xing, L.s., Zhang, B., Qiao, X., Liu, B., Liu, C.h., Xi, Y., Liu, W.x., Wang, W.k., Qian, W.q., MCkirdy, S. and Wan, F.h. (2021) Biology, Invasion and Management of the Agricultural Invader: Fall Armyworm, Spodoptera frugiperda (Lepidoptera: Noctuidae). Journal of Integrative Agriculture, 20, 646-663. https://doi.org/10.1016/S2095-3119(20)63367-6

[11] de Cássia Domingues, V., do Prado Ribeiro, L., Gonçalves, G.L.P., Forim, M.R., das Graças Fernandes da Silva, M.F., Fernandes, J.B. and Vendramim, J.D. (2020) Grain-Protectant Compounds from Duguetia lanceolata (Annonaceae) Derivatives: Bioassay-Guided Searching and Toxicity against the Maize Weevil. Journal of Stored Products Research, 85, Article ID: 101549. https://doi.org/10.1016/j.jspr.2019.101549

[12] Di Toto Blessing, L., Colom, O.Á., Popich, S., Neske, A. and Bardón, A. (2010) Antifeedant and Toxic Effects of Acetogenins from Annona montana on Spodoptera frugiperda. Journal of Pest Science, 83, 307-310. https://doi.org/10.1007/s10340-010-0299-0

[13] Hidalgo, J.R., Parellada, E.A., Blessing, L.D.T., Bardón, A., Ameta, K.L., Vera, N. and Neske, A. (2016) Natural and Derivatized Acetogenins Promising for the Control of Spodoptera frugiperda Smith. Journal of Agricultural Chemistry and Environment, 5, 200-210. https://doi.org/10.4236/jacen.2016.54021

[14] Hidalgo, J.R., Parellada, E.A., Bardón, A., Vera, N. and Neske, A. (2018) Insecticidal Activity of Annonaceous Acetogenins and Their Derivatives on Spodoptera frugiperda Smith (Lepidoptera: Noctuidae). Journal of Agricultural Chemistry and Environment, 7, 105-116. https://doi.org/10.4236/jacen.2018.73010

[15] Tolosa, D., Hidalgo, J.R., Sal, P.E., Popich, S., Bardón, A. and Neske, A. (2014) Insecticidal Effects of the Annonaceous Acetogenin Squamocin and the Acetogenin Fraction of Seeds of Rollinia occidentalis on Soybean and Corn Pests. Journal of Agricultural Chemistry and Environment, 3, 156-160. https://doi.org/10.4236/jacen.2014.34019

[16] Murúa, G. and Virla, E. (2004) Population Parameters of Spodoptera Frugiperda (Smith) (LEP.: Noctuidae) Fed on Corn and Two Predominant Grasess in Tucuman (Argentina). Acta Zoologica Mexicana, 20, 199-210.

[17] Blessing, L.D.T., Budeguer, F., Ramos, J., Bardón, A., Diaz, S., Brovetto, M., Seoane, G. and Neske, A. (2015) Structural Factors of Annonaceous Acetogenins and Their Semisynthetic Analogues Related with the Toxicity on Spodoptera frugiperda. Journal 
of Agricultural Chemistry and Environment, 4, 56-61.

https://doi.org/10.4236/jacen.2015.42006

[18] Ritchie, S.W. and Hanway, J.J. (1982) How a Corn Plant Develops. Iowa State University, Ames.

[19] Tshiabukole, J.P.K., Khonde, G.P., Phongo, A.M., Ngoma, N., Kankolongo, A.M., Vumilia, R.K. and Djamba, A.M. (2021) Simulation of Fall Armyworm (Spodoptera frugiperda) Attacks and the Compensative Response of Quality Protein Maize (Zea mays, var. Mudishi-1 and Mudishi-3) in Southwestern DR Congo. Open Access Library Journal, 8, 1-14. https://doi.org/10.4236/oalib.1107217 